\title{
An Empirical Analysis of the Impact of Internet Finance on Money Supply
}

\author{
Wei Min 1,2,a, \\ ${ }^{1}$ School of Business, Macau University of Science and Technology, Macau \\ ${ }^{2}$ College of Accounting and Finance, Guangdong Polytechnic of Science and Technology, Zhuhai, \\ China \\ aemail:409396954@qq.com
}

\begin{abstract}
Keywords: Internet finance; money supply; third-party payment; electronic money; cash leakage rate.
\end{abstract}

\begin{abstract}
The emergence and development of Internet finance has brought about a thorough subversion and profound transformation of traditional finance, which not only changed the supply and demand structure of money, but also had a profound impact on the transmission mechanism of monetary policy. Based on the analysis of the impact of Internet finance on the money supply, this paper chooses the money multiplier M1 and the money multiplier M2 based on the money multiplier theory as the explanatory variables, and the ratio EM and cash leakage of the third party payment total to the money supply M2. The damage rate $\mathrm{k}$ is used as an explanatory variable construction model for empirical analysis and corresponding policy recommendations are given.
\end{abstract}

\section{Introduction}

The emergence and development of internet finance has brought about a complete subversion and profound transformation of traditional finance. Taking third-party payment as an example, before the third-party payment is generated, the payment clearing system is that the customer establishes contact with the commercial bank, and the commercial bank establishes contact with the central bank. Since the customer cannot directly establish contact with the central bank, the customer must separately and each a commercial bank establishes contact and pays for liquidation is less efficient.

After the third-party payment is born, the customer established contact with the third-party payment company, and the third-party payment company replaces the customer to establish contact with the commercial bank. At this time, the third-party payment company becomes the counterparty of the customer and commercial bank payment settlement. The third-party payment company realizes a lot of trading funds through the intermediate accounts opened in different banks, and a small amount of interbank payment is cleared through the central bank's payment system to complete.

It can be seen that with the rise of Internet finance, especially the rapid development of third-party payment business, individual financial accounts no longer exclusively belong to traditional financial institutions. To a great extent, it greatly affects the original form, function, property and function of the currency, and has also changed the structure of the supply and demand of money. It has a far-reaching impact on the transmission mechanism of monetary policy.

\section{Research design}

\subsection{Sample selection}

The research objects chosen in this article are mainly quarterly data for the ten years between 2006 and 2016. The data comes from the official website of the People's Bank of China, the iResearch consulting website, and the wind database.

\subsection{Variable selection}

The retention currency (or deposit currency) in internet finance mainly comes from third-party payment, while the payment of electronic money by third parties will increase the money multiplier 
and promote the endogenous growth of money. The specific manifestations are three aspects: 1 . Electronic money has the characteristics of high liquidity. Commercial banks can quickly raise funds when funds are relatively short, so that banks can appropriately reduce the withdrawal of excess reserves, thereby increasing the money supply. 2. The use of electronic money can reduce the need for people to hold cash and reduce the cash leakage rate of commercial banks. 3. Electronic money has increased the efficiency of payment and settlement of funds, while the proportion of cash and demand deposits has fallen at the same time, while the proportion of fixed deposits with relatively high returns has increased, which has led to an increase in the currency multiplier.

Based on the above theoretical analysis, this paper will select the following variables when studying the impact of Internet finance on money supply:

Table 2.1 Variable definition

\begin{tabular}{|c|c|c|c|}
\hline & Name of Variable & $\begin{array}{l}\text { Symbol of } \\
\text { Variable }\end{array}$ & Definition of Variable \\
\hline \multirow[t]{2}{*}{$\begin{array}{l}\text { Explained } \\
\text { variable }\end{array}$} & $\begin{array}{l}\text { Currency multiplier } \\
\text { m1 }\end{array}$ & $m 1$ & $\begin{array}{c}\text { Narrow money supply M1 / } \\
\text { base currency }\end{array}$ \\
\hline & $\begin{array}{l}\text { Currency multiplier } \\
\text { m2 }\end{array}$ & $m 2$ & $\begin{array}{c}\text { Broad money supplyM2 / } \\
\text { base currency }\end{array}$ \\
\hline \multirow[t]{2}{*}{$\begin{array}{l}\text { Explanatory } \\
\text { variables }\end{array}$} & $\begin{array}{c}\text { Third Party Payment } \\
\text { Electronic Money } \\
\text { Replacement Rate }\end{array}$ & $E M$ & $\begin{array}{l}\text { Total third party payment } \\
\text { / Narrow money supply M1 }\end{array}$ \\
\hline & Cash leakage rate & $k$ & $\begin{array}{c}\text { Cash in circulation and } \\
\text { Broad money supplyM2 }\end{array}$ \\
\hline
\end{tabular}

Note: The base currency is the sum of cash in circulation and bank reserves.

Based on the raw data collected in this paper, the variables $\mathrm{m} 1, \mathrm{~m} 2, \mathrm{EM}$, and $\mathrm{k}$ are calculated as shown in Table 2.2.

Table2.2 Data for variables $\mathrm{m} 1, \mathrm{~m} 2, \mathrm{EM}$ and cash leakage rate $\mathrm{k}$

\begin{tabular}{|c|c|c|c|c|}
\hline Time & $m 1$ & $m 2$ & $E M$ & $k$ \\
\hline $2006 / 03$ & 1.24 & 3.61 & 0.0008 & 0.0756 \\
\hline $2006 / 06$ & 1.30 & 3.73 & 0.0008 & 0.0727 \\
\hline $2006 / 09$ & 1.27 & 3.61 & 0.0010 & 0.0774 \\
\hline $2006 / 12$ & 1.20 & 3.30 & 0.0010 & 0.0783 \\
\hline $2007 / 03$ & 1.23 & 3.49 & 0.0016 & 0.0752 \\
\hline $2007 / 06$ & 1.24 & 3.45 & 0.0013 & 0.0711 \\
\hline $2007 / 09$ & 1.22 & 3.35 & 0.0010 & 0.0739 \\
\hline $2007 / 12$ & 1.16 & 3.06 & 0.0015 & 0.0752 \\
\hline $2008 / 03$ & 1.12 & 3.14 & 0.0030 & 0.0719 \\
\hline $2008 / 06$ & 1.06 & 3.04 & 0.0035 & 0.0681 \\
\hline $2008 / 09$ & 1.04 & 3.04 & 0.0043 & 0.0700 \\
\hline $2008 / 12$ & 1.02 & 2.91 & 0.0051 & 0.0720 \\
\hline $2009 / 03$ & 1.12 & 3.36 & 0.0062 & 0.0636 \\
\hline $2009 / 06$ & 1.23 & 3.61 & 0.0068 & 0.0591 \\
\hline $2009 / 09$ & 1.19 & 3.44 & 0.0077 & 0.0628 \\
\hline $2009 / 12$ & 1.22 & 3.35 & 0.0083 & 0.0627 \\
\hline $2010 / 03$ & 1.21 & 3.44 & 0.0091 & 0.0601 \\
\hline $2010 / 06$ & 1.25 & 3.49 & 0.0098 & 0.0577 \\
\hline $2010 / 09$ & 1.20 & 3.43 & 0.0119 & 0.0601 \\
\hline $2010 / 12$ & 1.16 & 3.16 & 0.0135 & 0.0615 \\
\hline $2011 / 03$ & 1.12 & 3.19 & 0.0149 & 0.0592 \\
\hline $2011 / 06$ & 1.11 & 3.15 & 0.0168 & 0.0570 \\
\hline $2011 / 09$ & 1.03 & 3.04 & 0.0211 & 0.0599 \\
\hline $2011 / 12$ & 1.05 & 3.09 & 0.0255 & 0.0596 \\
\hline $2012 / 03$ & 1.01 & 3.24 & 0.0273 & 0.0554 \\
\hline $2012 / 06$ & 1.04 & 3.34 & 0.0296 & 0.0533 \\
\hline $2012 / 09$ & 0.99 & 3.26 & 0.0340 & 0.0566 \\
\hline $2012 / 12$ & 1.01 & 3.17 & 0.0394 & 0.0561 \\
\hline $2013 / 03$ & 1.01 & 3.35 & 0.0403 & 0.0535 \\
\hline $2013 / 06$ & 1.01 & 3.38 & 0.0428 & 0.0513 \\
\hline 2013/09 & 0.98 & 3.37 & 0.0483 & 0.0524 \\
\hline $2013 / 12$ & 1.02 & 3.36 & 0.0553 & 0.0529 \\
\hline
\end{tabular}




\begin{tabular}{lllll}
\hline $2014 / 03$ & 0.98 & 3.48 & 0.1020 & 0.0503 \\
$2014 / 06$ & 1.01 & 3.59 & 0.0944 & 0.0471 \\
$2014 / 09$ & 0.95 & 3.49 & 0.1066 & 0.0490 \\
$2014 / 12$ & 0.98 & 3.47 & 0.1189 & 0.0491 \\
$2015 / 03$ & 0.94 & 3.57 & 0.1314 & 0.0486 \\
$2015 / 06$ & 1.03 & 3.84 & 0.1435 & 0.0440 \\
$2015 / 09$ & 1.07 & 3.99 & 0.1508 & 0.0449 \\
$2015 / 12$ & 1.18 & 4.10 & 0.2044 & 0.0454 \\
$2016 / 03$ & 1.18 & 4.16 & 0.2493 & 0.0447 \\
$2016 / 06$ & 1.26 & 4.24 & 0.3156 & 0.0421 \\
\hline
\end{tabular}

\subsection{Model construction}

According to the above-determined variables, a regression model is used to construct the corresponding model. To make the data more stable, we take the variables $\mathrm{m} 1, \mathrm{~m} 2$, EM, and $\mathrm{k}$ respectively as logarithms. The multiple regression equations listed are as follows:

$$
\begin{aligned}
& \ln m 1=\alpha_{0}+\alpha_{1} \ln E M+\alpha_{2} \ln \mathrm{k} \\
& \ln m 2=\beta_{0}+\beta_{1} \ln E M+\beta_{2} \ln k
\end{aligned}
$$

\section{Empirical analysis and results}

First of all, descriptive statistical analysis of each variable, to get the mean, median, maximum, minimum, standard deviation and other information of each variable, as shown in Table 3.1.

Table3.1 Original variable descriptive statistics

\begin{tabular}{ccccccc}
\hline Variable & Mean & Median & Maximum & Minimum & $\begin{array}{c}\text { Standard } \\
\text { deviation }\end{array}$ & Observation \\
EM & 0.050248 & 0.015850 & 0.315600 & 0.000800 & 0.072998 & 42 \\
k & 0.059524 & 0.060000 & 0.080000 & 0.040000 & 0.011466 & 42 \\
m1 & 1.110476 & 1.115000 & 1.300000 & 0.940000 & 0.105274 & 42 \\
m2 & 3.425714 & 3.375000 & 4.240000 & 2.910000 & 0.305703 & 42 \\
\hline
\end{tabular}

In order to make the data more stable, to determine whether there is heteroscedasticity, we take the variables $\mathrm{m} 1, \mathrm{~m} 2, \mathrm{EM}$, and $\mathrm{k}$ as logarithms, denoted as $\operatorname{lnm} 1, \operatorname{lnm} 2$, InEM, lnk, and then perform the ADF stationarity test. The test results are as follows table:

Table3.2 Stability test of each variable

\begin{tabular}{cccccc}
\hline Variable & t Statistics & $1 \%$ & $5 \%$ & $10 \%$ & Conclusion \\
& & Critical value & Critical value & Critical value & \\
$\ln m 1$ & $-3.1978^{* *}$ & -3.6156 & -2.9411 & -2.6091 & smooth \\
$\ln m 2$ & $-5.8257^{* * *}$ & -3.6056 & -2.9370 & -2.6069 & smooth \\
$\ln E M$ & $-5.7474^{* * *}$ & -3.6105 & -2.9390 & -2.6079 & smooth \\
$\ln k$ & $-3.1147^{* *}$ & -3.6210 & -2.9434 & -2.6103 & smooth \\
\hline
\end{tabular}

Notes: $* * *$ indicates $\mathrm{p}<0.01, * *$ indicates $\mathrm{p}<0.05$, and $*$ indicates $\mathrm{p}<0.1$.

As shown in Table 3.2, the variables $\operatorname{lnm} 1$ and $\operatorname{lnk}$ are stable at the 5\% level, the variables $\operatorname{lnm} 2$ and $\operatorname{lnEM}$ are stable at the $1 \%$ level, and then they are regressed according to the model. The results are shown in Table 3.3 and 3.4. As shown.

\begin{tabular}{|c|c|c|c|c|}
\hline Variable & $\begin{array}{l}\text { Regression } \\
\text { coefficients }\end{array}$ & Standard error & t Statistics & P Value \\
\hline $\ln E M$ & -0.127659 & 0.027503 & -4.641689 & $0.0000 * * *$ \\
\hline $\ln k$ & -0.992369 & 0.274610 & -3.613741 & $0.0009^{* * *}$ \\
\hline $\mathrm{c}$ & -3.246677 & 0.891225 & -3.642938 & $0.0008 * * *$ \\
\hline otes: $* * *$ ind & \multicolumn{4}{|c|}{ Table 3.4 Variable $\mathrm{m} 2$ regression result } \\
\hline Variable & $\begin{array}{l}\text { Regression } \\
\text { coefficients }\end{array}$ & Standard error & t Statistics & P Value \\
\hline $\ln E M$ & 0.026914 & 0.030781 & 0.874384 & 0.3873 \\
\hline $\ln k$ & -0.465935 & 0.014441 & -32.26559 & $0.0000^{* * *}$ \\
\hline $\mathrm{c}$ & -0.006487 & 0.007018 & -0.924385 & 0.3610 \\
\hline
\end{tabular}

Table 3.3 Variable $\mathrm{m} 1$ regression result

Notes: $* * *$ indicates $\mathrm{p}<0.01$. 
From the above regression results, it can be seen that lnEM and lnk passed the significance test, indicating that the third-party payment electronic currency substitution rate (EM) and cash leakage rate $(\mathrm{k})$ have a significant influence on the money multiplier $\mathrm{m} 1$, but the money multiplier There is no significant effect of $\mathrm{m} 2$, which indicates that the current third-party payment electronic money substitution rate (EM) has not yet affected the higher-level money multiplier M2.

In addition, we also obtained from the regression results that there is a negative correlation between the third-party payment electronic currency substitution rate (EM) and the money multiplier $\mathrm{m} 1$, and the correlation with the currency multiplier $\mathrm{m} 2$ is not significant, which indicates that the third party payment service is fast Development has a significant substitution effect on traditional currencies. This substitution effect mainly focuses on cash and demand deposits in circulation, ie on the M1 currency level, but the substitution effect on savings and unit time deposits (ie, M2 currency level) is not significant. . Mainly because of the popularization and application of current third-party payment services, which reduces people's use of cash in the transaction process, and the reduced cash transfer to the third-party payment platform accounts represented by Alipay and Wechat Payments. It also shows that the increase in the demand for cash from other aspects of the M2 currency hierarchy is greater than the substitution effect of third-party payments on cash.

Similarly, as shown by the regression results, the cash leakage rate $(\mathrm{k})$ has a negative correlation with the money multiplier $\mathrm{m} 1$ and the money multiplier $\mathrm{m} 2$, which indicates that due to the obvious substitution effect on the current savings and cash due to the electronic payment currency, As a result, the bank's current deposits were increased, and the bank's loanable amount was increased, resulting in a decrease in the cash leakage rate. As the rate of cash leakage declines, the money supply will increase. It can be seen that although the popularity of third-party payment methods will not directly reduce the cash leakage rate, its popularity will increase the bank's idle funds and reduce the excess reserves. Ultimately, it has an impact on China's money supply.

\section{Policy implications}

Based on the above analysis, we believe that the development of Internet finance is a major change to the traditional trading methods. It is constantly affecting people's lifestyles and the country's economic development, especially the wide spread of third-party payment to cash in circulation. The substitution effect produced by current deposits and demand deposits is significant. At the same time, it also lowers the cash leakage rate, which in turn increases the credit creation ability of commercial banks and eventually increases the money supply. However, the rapid development of internet finance has also brought about certain negative impacts on the supply of money and demand as well as the currency transmission mechanism, weakening the promotion of monetary policy on the real economy and bringing great challenges to the central bank's macro regulation. Therefore, this article gives the following suggestions:

First, improve the transmission mechanism of monetary policy. With the gradual formation of the Internet financial credit creation mechanism, the central bank's monetary policy should make new adjustments. It can no longer be limited to the regulation of commercial banks' credit volume. It should establish a diversified credit transmission channel and strengthen the mechanism for creating Internet financial credit. Regulation, thereby enhancing the effect of currency transmission.

Second, reasonable encouragement of the healthy development of third-party payment. Third-party payment is the core of the current Internet financial business. Its birth greatly facilitates people's food, clothing, housing and transportation. Although third-party organizations have certain risks, the overall risk is controllable, so the regulatory authorities should create a favorable development environment for them.

Third, improve laws and regulations related to third-party payment supervision as soon as possible. Although Internet financial risks exist, they can be controlled. For example, monetary authorities can establish a standardized data monitoring system and data disclosure standards by using big data technology, and real-time data such as financing scale and capital flow of Internet 
financial markets. Monitoring, comprehensively grasp the basic situation of the industry, and then prevent the resolution of Internet financial risks.

\section{References:}

[1] Friedman, B. M, Targets and instrument of monetary policy, In B.M. Friedman and F.H. Hahn(eds.) Handbook of monetary economies, New York: North-Holland, 1990,(2):1185-1230.

[2] Jurgen Von Hagen \& Ingo Fender, Central Bank policy in a More perfect Financial System, Open Economies Review, 1998, (1):493-532.

[3] Miller, M, Financial Innovation: Achievements and prospects. Journal of applied Corporate Finance, 1992, (4).

[4] Palley Thomas, Monetary Policy in an era of financial deregulation and innovation, Journal of Economic Perspectives, 2002, (7).

[5] Chen Yulu, Bian Weihong, Development of Electronic Money and Risk Analysis of Central Bank, Studies of International Finance, 2002(1):53-58.

[6] Li Hongjin, Su Naifang, Hong Hao, Actual interest rate anchor in the regulation of price-type monetary policy, Economic Research Journal, 2016(1):42-54.

[7] Qian Xuesong, Du Li, Ma Wentao, A Study on the Effectiveness of Interest Rate Transmission in China's Monetary Policy: Mediating Effect and Differences within and beyond the System, Management World, 2015(11):11-28.

[8] Xie Ping,Zou Chuanwei, Research on Internet Financial Model ,Journal of Financial Research,2012(12).

[9] Xie Qinghe, Research on the Development of Internet Finance in China , Review of Economic Research,2013(49):29-36. 